\title{
Citra Program Pascasarjana PAI IAIN Padangsidimpuan dan Intensitas Word of Mouth di Kalangan Dosen
}

\author{
Muhammad Isa \\ IAIN Padangsidimpuan \\ misastmm@gmail.com

\section{Budi Gautama Siregar \\ IAIN Padangsidimpuan \\ budigautamasrg20@gmail.com}

\begin{abstract}
Abstrak Jumlah mahasiswa baru program pascasarjana S2 PAI IAIN Padangsidimpuan dari tahun 2016-2019 mengalami penurunan, sehingga penelitian ini dilakukan untuk menganalisis dan mendeskripsikan citra Program Pascasarjana (S2) PAI IAIN Padangsidimpuan di kalangan dosen Perguruan Tinggi Keagamaan Islam (PTKI) yang ada di wilayah Tapanuli serta mengetahui aktif atau tidaknya merekomendasikannya kepada orang lain. Populasi yang digunakan seluruh dosen dan sekaligus penasehat akademik pada PTKI yang ada dikawasan Tapanuli yang berjumlah 212. Teknik stratified random sampling digunakan dalam penentuan sampel yang berjumlah 53 dosen. Instrument pengumpulan data melalui kuesioner, sedangkan analisis data dengan teknik $F-F$ Scale. Hasil penelitian diperoleh bahwa 1) citra Program Pascasarjana (S2) PAI IAIN Padangsidimpuan di kalangan dosen masing-masing PTKI yang ada di wilayah Tapanuli cenderung positif dengan catatan tingkat pengenalan mereka terhadap program studi ini masih rendah. 2) Program Pascasarjana (S2) PAI IAIN Padangsidimpuan masih jarang menjadi topik pembicaraan (word of mouth) di kalangan dosen masing-masing PTKI yang ada di wilayah Tapanuli sehingga tingkat keaktifan mereka dalam merekomendasikan Program Pascasarjana S2 PAI IAIN Padangsidimpuan kepada orang lain masih jauh dari yang diharapkan
\end{abstract}

Kata Kunci Citra, word of mouth, PTKI

\section{PENDAHULUAN}

Pendidikan merupakan sebuah keniscayaan dalam meningkatkan kualitas sumber daya manusia, sesuai dengan yang diamanahkan dalam pembukaan UUD 1945 yaitu mencerdaskan kehidupan bangsa. Investasi yang paling urgen adalah bidang pendidikan yang akan melahirkan sumber daya manusia berkualitas dalam membawa bangsa ini kearah yang lebih baik dan berkembang. Pendidikan dijadikan sebagai salah indicator yang penting untuk mengukur besar atau kecilnya suatu bangsa, artinya semakin tinggi pendidikan masyarakat suatu bangsa maka bangsa tersebut dapat digolongkan kepada Negara yang besar (Magdalena,2020). 
Negara Indonesia memberikan kewenangan kepada Kementerian Agama untuk mengelola satuan pendidikan mulai dari tinkat Raudathul Athfal (RA) yang setingkat dengan satuan Pendidikan Anak Usia Dini (PAUD), Madrasah Ibtidaiyah (MI) setara dengan Sekolah Dasar (SD), Madrasah Tsanawiyah (MTs) setara dengan Sekolah Menengah Pertama (SMP), Madrasah Aliyah (MA) yang setara dengan Sekolah Menengah Atas (SMA) dan tingkat perguruan tinggi. Dalam pengelolaan perguruan tinggi yang dikelola oleh Kementerian Agama adalah Sekolah Tinggi Agama Islam Negeri (STAIN), Institut Agama Islam Negeri (IAIN) dan Universitas Islam Negeri (UIN).

Institut Agama Islam Negeri (IAIN) Padangsidimpuan yang bertransformasi dari Sekolah Tinggi Agama Islam Negeri (STAIN) Padangsidimpuan pada tahun 2014 merupakan salah satu PTKIN yang berada posisinya di Provinsi Sumatera Utara terus berbenah diri kearah yang semakin maju. Salah satu bukti perkembangan IAIN Padangsidimpuan adalah dengan membuka Program Pascasarjana (S2) Program Studi Pendidikan Agama Islam (PAI) pada tahun akademik 2013-2014. Program pascasarjana PAI IAIN Padangsidimpuan adalah satu-satunya yang ada diwilayah keresidenan Tapanuli yang mencakup Kabupaten/Kota yaitu Tapanuli Selatan, Mandailing Natal, Padang Lawas, Padang Lawas Utara, Kota Padangsidimpuan, Tapanuli Tengah, Kota Sibolga, Tapanuli Utara, Toba Samosir, Humbang Hasundutan, dan Samosir.

Sasaran utama sebagai calon mahasiswa baru program pascasarjana PAI IAIN Padangsidimpuan adalah mahasiswa yang memiliki latarbelakang prodi PAI. Terdapat 10 Perguruan Tinggi Keagamaan Islam (PTKI) yang berada diwilayah keresidenan Tapanuli yang memiliki prodi PAI/PGMI yaitu: 1) STAI Tapanuli Padangsidimpuan, 2) STAI Pertinu Padangsidimpuan, 3) STAI Barumun Raya Sibuhuan, 4) STIT YPIPL Gunung Tua Padang Lawas Utara, 5) STIT Muhammadiyah Sibolga, 6) STAI Bahriyatul Ulum Pandan, 7) STIT Hamzah Fansuri Baru Tapanuli Tengah, 8) FAI UMTS Padangsidimpuan, 9) STAIN Mandailing Natal Panyabungan dan 10) PAI IAIN Padangsidimpuan.

Citra yang ditampilkan perguruan tinggi merupakan salah satu faktor terpenting dalam menarik minat calon mahasiswa agar memutuskan diri untuk mendaftarkan dirinya. Dengan pembangunan citra akan menimbulkan kesan dalam diri seseorang tentang keberadaan sebuah perguruan tinggi tersebut dan biasanya diperolehnya melalui informasi, pengalaman, informasi serta pengetahuan yang dilalui dalam jangka waktu yang panjang. Citra perguruan tinggi yang ditampilkan tersebut dapat bersifat positif juga negatif. Citra yang positif ditandai dengan banyaknya orang yang mengenal dan juga menyenangi perguruan tinggi tersebut, sedangkan jika citranya negatif maka orang yang mengenal perguruan tinggi tersebut cenderung tidak akan menyenanginya.

Jika perguruan tinggi ingin memiliki jumlah mahasiswa yang banyak, maka citra positif perlu dijaga dan ditingkatkan dari waktu ke waktu. Untuk itu perlu dilakukan pemantauan secara berkala terhadap citra sebuah perguruan tinggi, misalnya melalui penelitian. Citra perguruan tinggi sangat berkaitan dengan kualitas pendidikan yang dijalankan pada perguruan tinggi tersebut. Oleh karena diperlukan adanya Total Quality Management (TQM) yang merupakan sebuah filosofi tentang perbaikan secara kontiniutas yang dapat memberikan seperangkat alat praktis kepada setiap institusi pendidikan dalam memenuhi kebutuhan mahasiswanya (Umiarso \& Imam, 2010:370).

Dalam upaya peningkatan tingkat pengenalan calon mahasiswa baru terhadap perguruan tinggi, maka diperlukan sosialisasi dan promosi. Promosi yang dilakukan 
bukan hanya bertujuan untuk mengenalkan perguruan tinggi tersebut, namun juga berusaha untuk menimbulkan minat sekaligus mengajaknya untuk segera mendaftarkan diri pada perguruan tinggi itu. Media dalam melakukan promosi dapat dilakukan dengan berbagai cara yaitu mulai dari yang paling sederhana dan murah yaitu dengan cerita dari mulut ke mulut (mouth to mouth) hingga dengan menggunakan media digitalisasi berupa iklan televisi, media sosial dan lainnya.

Strategi promosi dengan dengan cara mouth to mouth merupakan media yang paling murah dan sederhana namun sangat efektif karena akan langsung dapat mempengaruhi seseorang secara emosional. Perguruan tinggi harus melakukan pengukuran terkait seberapa sering lembaga tersebut dijadikan sebagai topik pembicaraan di tengah-tengah masyarakat yang dikatakan dengan word of mouth. Word of mouth merupakan tindakan dalam merekomendasikan secara lisan tentang perguruan tinggi kepada orang lain karena menurutnya perguruan tinggi tersebut tergolong baik dan memberikan kualitas yang terjamin.

Masyarakat yang mengenal baik dengan perguruan tinggi tersebut akan mengakibatkan kemungkinan akan memperoleh calon mahasiswa baru yang lebih banyak pula. Tingkat intesitas word of mouth yang tinggi akan dapat mempercepat pengenalan perguruan tinggi tersebut kepada masyarakat luas. Kondisi mahasiswa pascasarjana PAI IAIN Padangsidimpuan dalam kurun empat tahun terakhir mengalami penurunan, seperti terlihat dalam tabel berikut:

\section{Tabel 1}

Jumlah Mahasiswa Pascasarjana PAI IAIN Padangsidimpuan

\begin{tabular}{cccc}
\hline No. & Tahun & Pendaftar & Lulus Seleksi \\
\hline 1. & 2016 & 57 & 54 \\
2. & 2017 & 56 & 54 \\
3. & 2018 & 49 & 48 \\
4. & 2019 & 32 & 31 \\
\hline
\end{tabular}

Sumber: Kantor Program pascasarjana IAIN Padangsidimpian

Berdasarkan tabel diatas menunjukkan bahwa jumlah mahasiswa pascasarjana PAI IAIN Padangsidimpuan dari tahun ke tahun mengalami penurunan, tentu hal ini tidak boleh dibiarkan. Salah satu upaya yang dapat dilakukan dalam menambah peminat calon mahasiswa adalah dengan memaksimalkan peran para dosen di PTKI yang berada di wilayah Tapanuli untuk lebih aktif merekomendasikan program pascasarjana PAI kepada para mahasiswanya.

Citra dari program pascasarjana PAI IAIN Padangsidimpuan harus terus dibangun agar tercipta kepercayaan, ide dan impresi seseorang sehingga dapat meningkatkan minatnya untuk menjadi calon mahasiswa (Buchari, 2018:317).

Dengan menciptakan menciptakan citra yang positif akan memberikan kesan, perasaan, konsepsi yang baik pada publik mengenai program pascasarjana PAI IAIN Padangsidimpuan. Pembentukan citra yang positif dapat tercapai dari aktivitas operasional perguruan tinggi sehari-hari dengan melandaskannya pada pelayanan yang prima. Dalam penelitiannya (Rifka dkk.:2015) menemukan bahwa kepuasan dan loyalitas mahasiswa dipengaruhi oleh citra yang dibangun oleh institusi tersebut. Mahasiswa yang merasa puas akan pelayanan yang dberikan oleh perguruan tinggi akan dengan sendirinya 
memberikan rekomendasi kepada orang lain untuk melanjutkan studi di perguruan tinggi tersebut.

\section{LANDASAN TEORI \\ 1. Citra}

Citra terhadap perguruan tinggi terbentuk berdasarkan beberapa komponen sebagaimana disampaikan oleh Huddleston yang dikutip oleh Alma yaitu reputasi akademis atau mutu akademik dari perguruan tinggi, penampilan kampus, biaya, lokasi, jarak dari rumah tempat tinggal, kemungkinan karir masa depan, kegiatan sosial dari lembaga dan lainnya (Buchari, 2018:382). Citra suatu perguruan tinggi perlu dipantau secara rutin dari waktu ke waktu melalui riset pemasaran secara berkesinambungan. Riset pemasaran merupakan perancangan, pengumpulan, analisis, dan pelaporan data dari temuan secara sistematis, yang relevan dengan situasi pemasaran tertentu yang dihadapi perguruan tinggi (Hery, 2019:64).

Pemasaran perguruan tinggi bersifat abstrak karena yang dipasarkan tidak berwujud serta tidak menyebabkan perpindahan kepemilikan (Ratih, 2015:27). Untuk memasarkan jasa yang ditawarkan perguruan tinggi harus menetapkan strategi yang terbaik agar tujuan dan sasaran jangka panjang dapat ditentukan(Utari, 2016).

\section{Promosi Word of Mouth}

Promosi word of mouth adalah merekomendasikan kepada kerabat, teman, maupun relasi untuk mau menjadi calon mahasiswa baru bagi perguruan tinggi tersebut. Kegiatan promosi word of mouth ini akan efektif bila mahasiswa perguruan tinggi tersebut memperoleh kepuasan dari pelayanan yang diberikan. Kepuasan adalah tingkat perasaan seseorang setelah membandingkan kinerja (hasil) yang dirasakan dibandingkan dengan harapannya. Jadi tingkat kepuasan adalah fungsi dari perbedaan antara kinerja yang dirasakan dengan harapan seseorang (Susatyo, 2014:77)

Beberapa penelitian telah dilakukan (SL\& Rahayu, 2016), (Indah \&Rieke, 2017), (Ina, 2016), dimana dengan aktivitas word of mouth marketing, produsen dapat memanfaatkan para pelanggan potensialnya untuk memberikan kontribusi merubah konsumen lainnya menjadi bersikap positif terhadap produk yang dipasarkan. Para pelanggan ini merupakan profitable talkers yang memiliki jaringan serta pengaruh yang besar untuk mempengaruhi konsumen lainnya bersikap positif, mencoba dan membeli produk.

\section{METODOLOGI PENELITIAN}

Jenis penelitian ini adalah kuantitatif deskriptif yang akan mendeskripsikan citra program pascasarjana (S2) Pendidikan Agama Islam IAIN Padangsidimpuan dan intensitas word of mouth di kalangan dosen perguruan tinggi keagamaan islam sekawasan Tapanuli. Populasi penelitian ini adalah seluruh dosen yang mengajar dan sekaligus sebagai Penasehat Akademik di prodi S1 PAI pada PTKI di wilayah Tapanuli yang berjumlah 10 perguruan tinggi, yaitu STAI Tapanuli Padangsidimpuan, STAI Pertinu Padangsidimpuan, STAI Barumun Raya Sibuhuan Padang Lawas, STIT YPIPL Gunung Tua Padang Lawas Utara, STIT Muhammadiyah Sibolga, STAI Bahriyatul Ulum Sibolga, STIT Hamzah Fansuri Barus Tapanuli Tengah, FAI UMTS Padangsidimpuan, STAIN Mandailing Natal Panyabungan dan IAIN Padangsidimpuan 
Jumlah dosen PA pada Prodi S-1 PAI Perguruan Tinggi Keagamaan Islam se-Kawasan Tapanuli adalah sebanyak 212 orang.

Penentuan sampel dilakukan dengan merujuk pada pendapatnya (Suharsimi, 1993: 107) yaitu $25 \%$ dari jumlah populasi (212), sehingga diperoleh 53 dosen. dalam penelitian ini digunakan sampel sebanyak $25 \%$ x $212=53$ orang. Teknik sampling yang digunakan adalah stratified random sampling sehingga jumlah sampel dari masingmasing PTKI, seperti terlihat pada tabel berikut:

Tabel 2

Populasi dan sampel

\begin{tabular}{llcc}
\hline No & \multicolumn{1}{c}{ Nama PTKI } & $\begin{array}{c}\text { Jumlah Dosen PA } \\
\text { (orang) }\end{array}$ & $\begin{array}{c}\text { Sampel } \\
\text { (orang) }\end{array}$ \\
\hline 1 & STAI Tapanuli & 12 & 3 \\
2 & STAI Pertinu & 12 & 3 \\
3 & STAI Barumun Raya & 18 & 5 \\
4 & STIT YPIPL Gunung Tua & 21 & 5 \\
5 & STIT Muhammadiyah Sibolga & 16 & 4 \\
6 & STAI Bahriyatul Ulum & 21 & 5 \\
7 & STIT Hamzah Fansuri & 12 & 3 \\
8 & FAI UMTS Padangsidimpuan & 18 & 5 \\
9 & STAIN Madina & 25 & 6 \\
10 & IAIN Padangsidimpuan & 57 & 14 \\
& Total & $\mathbf{2 1 2}$ & $\mathbf{5 3}$ \\
\hline
\end{tabular}

Sumber: Bagian Akademik PTKI se-Kawasan Tapanuli

Teknik pengumpulan data dilakukan dengan penyebaran kuesioner yang terdiri dari pengukuran pengenalan, sikap, keaktifan dalam mengkomunikasikan melalui mulut ke mulut (word of mouth). Teknik analisis data dilakukan dengan teknik riset pemasaran yaitu $F$ - $F$ scale (familiarity dan favorable). Langkah-langkah yang dilakukan yaitu melakukan pengukuran pengenalan, sikap dan memahami citra, kemudia jawaban dari pertanyaan kuesiner akan diringkas dalam diagram yang terdiri dari empat kuadran dengan skala 1 s.d 5 yaitu:

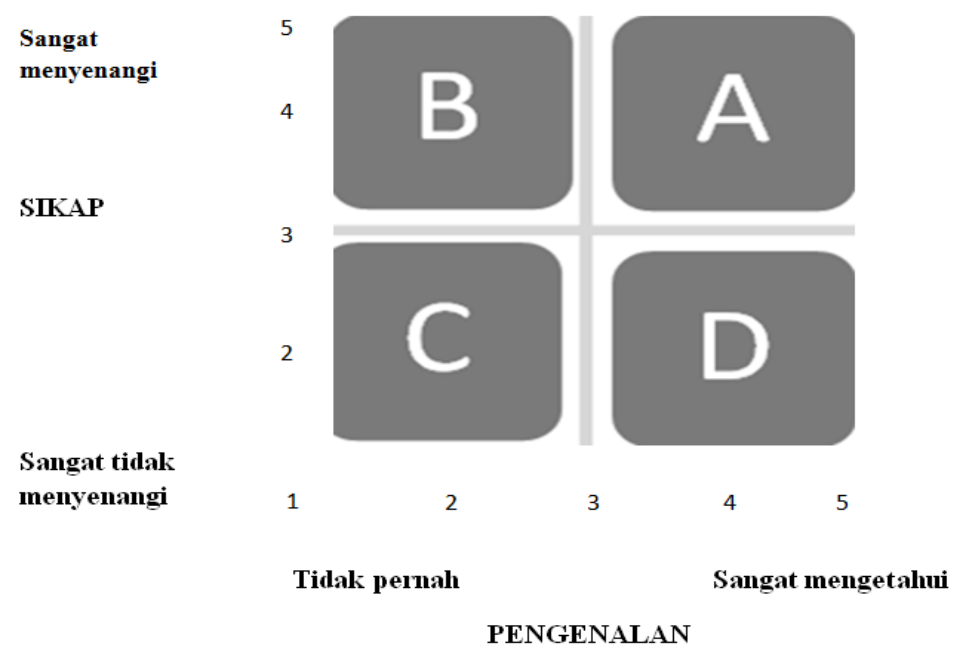

Gambar 1. Matriks F-F scale 


\section{HASIL PENELITIAN}

Untuk mengetahui citra Program Pascasarjana (S2) PAI IAIN Padangsidimpuan, ada tiga langkah yang harus dilakukan yaitu:

a. Mengukur pengenalan,

b. Mengukur Sikap, dan

c. Memahami citra.

\section{Pengukuran Pengenalan Dosen PTKI}

Pengolahan data tentang pengenalan diperoleh rata-rata skor sebesar 2,64 yang posisinya berada dalam rentang 1-5, sehingga dapat diketahui bahwa tingkat pengenalan Dosen PTKI se-kawasan Tapanuli terhadap Program Pascasarjana S2 PAI IAIN Padangsidimpuan berada di antara "Pernah Dengar" dengan "Tahu Sedikit". Kondisi ini menunjukkan bahwa umumnya dosen-dosen Prodi PAI pada PTKI se-kawasan Tapanuli belum cukup mengetahui keberadaan Program Pascasarjana S2 PAI IAIN Padangsidimpuan. Maka yang harus dilakukan adalah melakukan sosialisasi dan pengenalan yang lebih intensif dan massif.

\section{Pengukuran Sikap Dosen PTKI}

Data tentang sikap diperoleh nilai rata-rata sebesar 3,04 dimana posisinya berada dalam rentang 1-5. Skor menunjukkan bahwa sikap para Dosen PTKI se-kawasan Tapanuli terhadap Program Pascasarjana S2 PAI IAIN Padangsidimpuan berada di antara "Netral" dengan "Menyenangi". Artinya para dosen Prodi PAI pada PTKI se-kawasan Tapanuli secara umum memiliki sikap lebih cenderung netral dalam menyikapi keberadaan Program Pascasarjana S2 PAI IAIN Padangsidimpuan. Namun dari skor tersebut terlihat ada indikasi bahwa secara umum sikap mereka menuju ke arah "Menyenangi". Hal ini menunjukkan bahwa IAIN Padangsidimpuan masih memiliki kesempatan besar untuk membantu masyarakat, terutama para dosen Prodi PAI sekawasan Tapanuli untuk menyenangi Program Pascasarjana S2 PAI IAIN Padangsidimpuan.

\section{Memahami Citra Program Pascasarjana S2 PAI IAIN Padangsidimpuan di kalangan Dosen PTKI se-Kawasan Tapanuli}

Dalam menentuan bagaimanakah posisi citra program pascasarjana S2 PAI IAIN Padangsidimpuan dilakukan dengan mencari titik potong skor pengenalan dan sikap yang dimasukkan dalam matrik $F$-F Scale, seperti berikut ini:

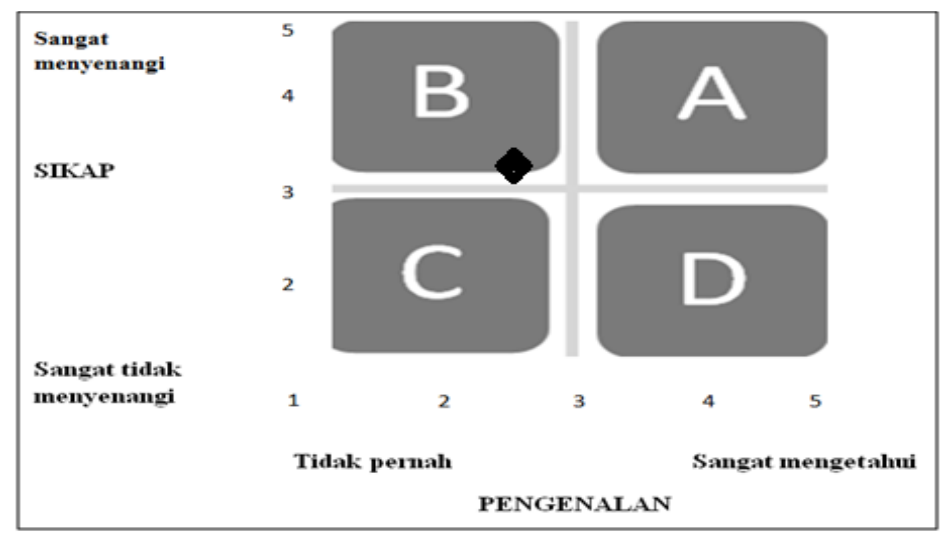

Gambar 2. Hasil Plot Matriks F-F scale 
Skor tingkat pengenalan $(2,64)$ dan skor sikap Dosen PTKI se-Kawasan Tapanuli terhadap Program Pascasarjana S2 PAI IAIN Padangsidimpuan $(3,04)$ diplot ke dalam matriks di atas, sehingga titik perpotongannya berada pasa posisi kuadran B. Hal ini menunjukkan bahwa Program Pascasarjana S2 PAI IAIN Padangsidimpuan secara umum masih kurang dikenal para dosen PAI pada PTKI se-Kawasan Tapanuli. Jika pun mereka mengetahui keberadaannya, pengetahuan mereka tentang Program Pascasarjana S2 PAI IAIN Padangsidimpuan masih sangat sedikit. Tetapi bagi mereka yang sudah mengenal keberadaannya, mereka cenderung menyenanginya atau dengan kata lain Program Pascasarjana S2 PAI IAIN Padangsidimpuan memiliki citra yang positif di benak mereka. Yang harus dilakukan pihak pengelola Program Pascasarjana S2 PAI IAIN Padangsidimpuan ke depan adalah berusaha untuk memperkenalkannya kepada lebih banyak orang.

\section{Intensitas Komunikasi Mulut ke Mulut dalam Merekomendasikan Program Pascasarjana S2 PAI IAIN Padangsidimpuan (Word of Mouth)}

Instrumen yang digunakan dalam penelitian dilakukan pengujian validitas dan reliabilitas, selanjutnya engukuran intensitas word of mouth dilakukan dengan uji t satu sampel (one sampel test). Dari hasil pengujian dengan bantuan SPSS dapat diketahui bahwa seluruh nilai signifikansi tiap butir kuesioner jauh di bawah 0,05. Artinya seluruh butir kuesioner yang digunakan dalam penelitian ini memenuhi syarat validitas. Sedangkan dari nilai Cronbach's Alpha sebesar 0,925>0,6. Artinya seluruh butir kuesioner yang digunakan dalam penelitian ini reliabel.

Kemudian dari hasil uji t diperoleh sebagai berikut:

One-Sample Statistics

\begin{tabular}{|l|r|r|r|c|}
\hline & N & Mean & $\begin{array}{c}\text { Std. } \\
\text { Deviation }\end{array}$ & $\begin{array}{c}\text { Std. Error } \\
\text { Mean }\end{array}$ \\
\hline Data & 53 & 2,8703 &, 70240 &, 09648 \\
\hline
\end{tabular}

One-Sample Test

\begin{tabular}{|c|c|c|c|c|c|c|}
\hline & \multicolumn{6}{|c|}{ Test Value $=2.9$} \\
\hline & \multirow[t]{2}{*}{$\mathrm{t}$} & \multirow[t]{2}{*}{ df } & \multirow[t]{2}{*}{$\begin{array}{l}\text { Sig. (2- } \\
\text { tailed) }\end{array}$} & \multirow[t]{2}{*}{$\begin{array}{c}\text { Mean } \\
\text { Difference }\end{array}$} & \multicolumn{2}{|c|}{$\begin{array}{l}95 \% \text { Confidence Interval of } \\
\text { the Difference }\end{array}$} \\
\hline & & & & & Lower & Upper \\
\hline Data &,- 308 & 52 &, 75 &,- 02972 &,- 2233 &, 1639 \\
\hline
\end{tabular}

Intensitas word of mouth yang diharapkan serendahnya adalah "sering" yang di

dalam kuesioner diberikan skor 3. Dengan kata lain jika jawaban responden memiliki rata-rata skor lebih dari 2,9 maka Program Pascasarjana S2 PAI IAIN Padangsidimpuan sering menjadi bahan pembicaraan para dosen PAI pada PTKI se-kawasan Tapanuli dan merekomendasikannya kepada oranglain.

Nilai signifikansi yang diperoleh adalah $0,759>0,05(\alpha)$, sehingga $\mathrm{H}_{0}$ diterima dan $\mathrm{H}_{1}$ ditolak. Artinya Program Pascasarjana S2 PAI IAIN Padangsidimpuan masih jarang menjadi topik pembicaraan kalangan dosen PAI pada PTKI se-Kawasan Tapanuli. Hal ini juga berarti para dosen PAI tersebut masih kurang aktif dalam merekomendasikan Program Pascasarjana S2 PAI IAIN Padangsidimpuan kepada orang lain. 


\section{Pembahasan}

a. Pengenalan Dosen PTKI se-Kawasan Tapanuli terhadap Program Pascasarjana S2 PAI IAIN Padangsidimpuan

Dari hasil penelitian yang dilakukan diketahui bahwa secara umum dosendosen PTKI se-Kawasan Tapanuli belum cukup mengetahui keberadaan Program Pascasarjana S2 PAI IAIN Padangsidimpuan. Hai ini mungkin saja disebabkan wilayah Tapanuli yang cukup luas dan keberadaan program studi ini ini yang masih relatif baru. Banyak hal yang dapat dilakukan untuk meningkatkan taraf pengenalan masyarakat akademisi, terutama dosen-dosen PTKI, terhadap keberadaan program studi ini. Kegiatan tersebut antara lain dengan melakukan pendekatan kepada instansi-instansi terkait misalnya Kantor Kementerian Agama Kabupaten /Kota yang membawahi dan membina madrasah, Dinas Pendidikan Daerah, maupun Pemerintah Kabupaten/Kota. Kemudian seiring dengan kondisi saat ini yang mana penggunaan teknologi informasi sedang maraknya, maka sosialisasi program studi melalui jaringan internet dan media sosial perlu dipertimbangkan samping cara-cara sosialisasi yang konvensional.

Metode yang yang sederhana untuk ditempuh dalam rangka sosialisasi program studi ini dapat dilakukan dengan memasang spanduk di tempat-tempat yang strategis. Selain itu dapat juga ditempuh dengan cara menjadi donatur untuk membangun tugu atau plang merk Kantor Sekolah atau Madrasah, tetapi dengan mengikutsertakan nama program studi Program Pascasarjana S2 PAI IAIN Padangsidimpuan sebagai donatur atau sponsor pendirian tugu atau plang merk tersebut.

b. Sikap Dosen Dosen PTKI se-Kawasan Tapanuli terhadap Program Pascasarjana S2 PAI IAIN Padangsidimpuan

Berdasarkan hasil penelitian yang dilakukan diketahui bahwa sikap para dosen PTKI se-Kawasan Tapanuli terhadap Program Pascasarjana S2 PAI IAIN Padangsidimpuan berada di antara "Netral" dengan "Menyenangi". Hal ini menunjukkan bahwa para dosen Prodi PAI pada PTKI se-Kawasan Tapanuli secara umum memiliki sikap lebih cenderung netral dalam menyikapi keberadaan Program Pascasarjana S2 PAI IAIN Padangsidimpuan. Namun dari skor yang diperoleh dalam penelitian ini terlihat ada indikasi bahwa secara umum sikap mereka cenderung menuju ke arah "Menyenangi".

Hal di atas menunjukkan ada sisi potensial yang dapat ditingkatkan agar para dosen PTKI se-Kawasan Tapanuli lebih menyenangi Program Pascasarjana S2 PAI IAIN Padangsidimpuan. Peluang ini harus dimanfaatkan, dengan cara mendorong mereka agar lebih bersikap positif dalam menanggapi keberadaan Program Pascasarjana S2 PAI IAIN Padangsidimpuan. Hal ini dilakukan misalnya dengan memberikan insentif atau hadiah bagi dosen yang telah merekomendasikan mahasiswa baru untuk program studi ini. Insentif yang diberikan tidak harus berbentuk uang atau materi. Namun dapat juga diberikan berupa sertifikat, piagam penghargaan atau cinderamata sederhana lainnya.

c. Citra Program Pascasarjana S2 PAI IAIN Padangsidimpuan di kalangan Dosen PTKI se-Kawasan Tapanuli

Berdasarkan hasil penelitian yang dilakukan diperoleh informasi bahwa para dosen PTKI se-Kawasan Tapanuli cenderung menyenangi program studi ini. Dengan kata lain Program Pascasarjana S2 PAI IAIN 
Padangsidimpuan memiliki citra yang positif di benak mereka. Hal ini mengindikasikan bahwa jika sosialisasi dilakukan dengan tepat, mMedia yang digunakan juga sesuai, maka harapan untuk memperoleh calon mahasiswa baru yang lebih banyak akan mudah untuk dicapai. Hal ini dikarenakan citra program studi ini sebenarnya sudah baik di mata para dosen PTKI se-Kawasan Tapanuli tersebut. Yang perlu dilakukan selanjutnya adalah kegiatan sosialisasi dan promosi yang lebih intensif, memilih metode yang paling tepat, waktu yang paling tepat, serta audiens atau khalayak masyarakat yang dituju juga tepat.

d. Intensitas komunikasi mulut ke mulut dalam merekomendasikan Program Pascasarjana (S2) PAI IAIN Padangsidimpuan kepada orang lain (word of mouth)

Dari hasil penelitian yang dilakukan diperoleh kenyataan bahwa Program Pascasarjana S2 PAI IAIN Padangsidimpuan masih jarang menjadi topik pembicaraan kalangan dosen PAI pada PTKI se-Kawasan Tapanuli. Hal ini juga berarti para dosen PAI tersebut masih kurang aktif dalam merekomendasikan Program Pascasarjana S2 PAI IAIN Padangsidimpuan kepada orang lain. Hal ini penting menjadi perhatian serius pengelola program studi ini.

Dari perhitungan yang dilakukan diperoleh bahwa nilai intensitas word of mouth terendah ada pada dosen PAI Universitas Muhammadiyah Tapanuli Selatan UMTS) dan STIT Muhammadiyah Sibolga. Di masa yang akan datang sosialisasi dan promosi kepada kedua perguruan tinggi ini perlu diintensifkan dan dirancang sebaik mungkin sehingga lebih mendorong para akademisi di kedua perguruan tinggi ini untuk lebih mengenal dan lebih sering membicarakan keberadaan program studi S2 PAI IAIN Padangsidimpuan.

Cara yang dapat ditempuh antara lain dengan menyumbangkan buku-buku karya dosen IAIN Padangsidimpuan maupun karya ilmiah untuk menjadi bahan rujukan bagi dosen-dosen di PTKI tersebut. Buku-buku dan karya ilmiah yang dimaksud dapat diberikan secara gratis kepada para dosen atau sebagian disumbangkan ke perpustakaan perguruan tinggi tersebut. Dengan cara ini diharapkan ketika mereka mengajar mereka akan teringat dengan keberadaan IAIN Padangsidimpuan. Selain itu dapat juga ditempuh cara lain berupa kegiatan seminar maupun kompetisi ilmiah yang melibatkan kedua perguruan tinggi tersebut dan di dalamnya diselipkan acara promosi dan sosialisasi program studi S2 PAI IAIN Padangsidimpuan.

Sedangkan nilai intensitas word of mouth tertinggi ada pada dosen PAI IAIN Padangsidimpuan dan disusul oleh STAI Barumun Raya Sibuhuan. Hal ini merupakan suatu kewajaran karena dosen-dosen Prodi PAI IAIN Padangsidimpuan dimungkinkan memiliki rasa sense of belonging yang lebih tinggi terhadap almamater tempatnya mengabdi. Sedangkan nilai intensitas word of mouth yang tinggi pada dosen-dosen Prodi PGMI STAI Barumun Raya dimungkinkan karena tingginya interaksi kedua perguruan tinggi ini sebelumnya. Di mana banyak dosen IAIN Padangsidimpuan yang pernah mengabdi dan mengajar di STAI Barumun Raya sebelum berkarir di IAIN Padangsidimpuan. 


\section{KESIMPULAN} berikut ini:

Dari hasil pengolahan dan pembahasan dalam penelitian, dapat ditarik kesimpulan

1. Citra Program Pascasarjana (S2) PAI IAIN Padangsidimpuan di kalangan dosen masing-masing PTKI yang ada di wilayah Tapanuli cenderung positif dengan catatan tingkat pengenalan mereka terhadap program studi ini masih rendah.

2. Program Pascasarjana (S2) PAI IAIN Padangsidimpuan masih jarang menjadi topik pembicaraan (word of mouth) di kalangan dosen masing-masing PTKI yang ada di wilayah Tapanuli sehingga tingkat keaktifan mereka dalam merekomendasikan Program Pascasarjana S2 PAI IAIN Padangsidimpuan kepada orang lain masih jauh dari yang diharapkan.

Penelitian ini masih memiliki keterbatasan dimana peneliti tidak dapat memberikan jaminan kejujuran responden dalam menjawab kuesiner penelitian ini. Penelitian ini dapat dilanjutkan dan dikembangkan dengan topik yang lebih luas lagi dengan metode yang berbeda.

\section{UCAPAN TERIMA KASIH}

Penulis mengucapkan terima kasih kepada Dirjen Diktis Kementerian Agama yang telah membantu pendanaan terlaksananya penelitian ini melalui Bantuan Penelitian BOPTN 2020.

\section{DAFTAR PUSTAKA}

Arsip Rekapitulasi Penerimaan Mahasiswa Baru Pascasarjana IAIN Padangsidimpuan Buchari Alma, Manajemen Pemasaran \& Pemasaran Jasa, Bandung: Alfabeta, 2018 Pemasaran Stratejik Jasa Pendidikan, Bandung: Alfabeta, 2003 Enung K. Rukiati, Sejarah Pendidikan Islam di Indonesia, Bandung:Pustaka Setia, 2006. Hery, Manajemen Pemasaran, Jakarta: PT. Grasindo, 2019.

Muhammad Adam, Manajemen Pemasaran Jasa, Bandung: Alfabeta,2015.

Ratih Hurriyati, Bauran Pemasaran dan Loyalitas konsumen, Bandung: Alfabeta, 2015.

Sambas Ali Muhidin dan Maman Abdurrahman, Analisis Korelasi, Regresi dan Jalur dalam Penelitian, Bandung:Pustaka Setia, 2009.

Suharsimi Arikunto, Prosedur Penelitian, Jakarta: Rineka Cipta, 1993.

Susatyo Herlambang, Basic Marketing (Dasar-dasar Pemasaran): Cara Mudah Memahami Ilmu Pemasaran, Yogyakarta:Gosyen Publishing, 2014

Umiarso,dkk. , Manajemen Mutu Sekolah di Era Otonomi Pendididikan, Yogyakarta: IRCISoD, 2010. V.

\section{Sumber Jurnal}

Indah Nur Agustiani dan Rieke Sri Rizki Asti Karini, "Pengaruh Word of Mouth Marketing Terhadap Citra Perguruan Tinggi dan Dampaknya Terhadap Keputusan Menjadi Mahasiswa di STKIP Pasundan Cimahi”, dalam Tourism Scientific Journal, Volume 3, Nomor 1, Desember 2017.

Ina Ratnasari, "Pengaruh Kualitas Pelayanan dan Citra Institusi Terhadap Kepuasan Mahasiswa Yang Berdampak Pada Word of Mouth (Studi Kasus Pada Mahasiswa 
Universitas Singaperbangsa Karawang)", dalam Value Journal Of Management and Business, Volume 1, Nomor 1, Oktober 2016.

Magdalena, "Penjaminan Mutu Pendidikan Islam di Sekolah Tinggi Ilmu Tarbiyah (STIT) Muhammadiyah Sibolga Tapanuli Tengah", dalam Jurnal Al-Fatih: Jurnal Pendidikan dan Keislaman, Volume III, Nomor 1, Januari-Juni 2020, hal. 20-38.

Rifka Arinda Noviasari, dkk., "Pengaruh Citra Institusi dan Kualitas Layanan Terhadap Kepuasan dan Loyalitas Mahasiswa Universitas Moch. Sroedji Jember" dalam Jurnal Bisma, Volume 9, Nomor 2, Juli 2015.

SL. Triyaningsih dan Rahayu Triastity, "Pengaruh Citra Perguruan Tinggi Terhadap Keputusan Mahasiswa Memilih Perguruan Tinggi dengan Word of Mouth Sebagai Variabel Intervening (Studi Pada Mahasiswa Fakultas 67 Ekonomi Unisri Surakarta)," dalam Jurnal Eksplorasi, Volume 29, Nomor 1, Agustus 2016.

Utari Evy Cahyani, "Strategi Bersaing Dalam berbisnis Secara Islami”, dalam Jurnal AtTijaroh, Volume 2, Nomor 1, Januari-Juni 2016. 